\title{
Warok Dance: A Medium of Child Aesthetic Fulfillment
}

\author{
Hartono, Agus Cahyono*, Eny Kusumastuti \\ Faculty of Language and Art, State University of Semarang, Semarang, Indonesia
}

Received September 23, 2020; Revised February 19, 2021; Accepted February 26, 2021

\begin{abstract}
Cite This Paper in the following Citation Styles
(a): [1] Hartono, Agus Cahyono, Eny Kusumastuti , "Warok Dance: A Medium of Child Aesthetic Fulfillment," International Journal of Human Movement and Sports Sciences, Vol. 9, No. 2, pp. 242-249, 2021. DOI: 10.13189/saj.2021.090212.
\end{abstract}

(b): Hartono, Agus Cahyono, Eny Kusumastuti (2021). Warok Dance: A Medium of Child Aesthetic Fulfillment. International Journal of Human Movement and Sports Sciences, 9(2), 242-249. DOI: 10.13189/saj.2021.090212.

Copyright $\bigcirc 2021$ by authors, all rights reserved. Authors agree that this article remains permanently open access under the terms of the Creative Commons Attribution License 4.0 International License

\begin{abstract}
Dance can serve as an effective medium to instill aesthetic values for children given the many artistic elements of this type of art including movement, music, visual, and performance. For this reason, incorporating dances is an appropriate medium to introduce the aspects of aesthetics to children. This literature review specifically analyzed the elements of the Warok Dance that actualizes the fulfillment of aesthetic values and how the children express their aesthetic needs. The data from the observation and interview were interactively analyzed; its stages involved data display, data reduction, and verification. The results showed that the medium of expression of aesthetic needs involves the elements of movements, music, makeup, and costume of the Warok dance. The fulfillment of aesthetic needs in the dance was conducted directly and indirectly. As appreciators, the children were directly involved in the dance practice and performance sessions. Moreover, the children were also indirectly involved into the dance when they watched their peers practice and perform the dance. In particular, the study concludes that the elements of Warok dance serve as the medium of fulfillment and expression of children's aesthetic needs, either by participating into the dance directly, or by watching their peers perform the dance (indirectly).
\end{abstract}

Keywords Child, Aesthetic, Warok Dance

\section{Introduction}

Warok dance is considered as among the results of civilization and cultural development in the place it was firstly performed. Community support is essential to the cultural preservation efforts of the dance, particularly support from the society that concerns on arts field. As a legacy from the ancient times, the dance embeds values of great significance to the societal life. Murgiyanto [23] argues that the traditional arts contain meaningful values and norms to pass down to future generations. Therefore, to maintain the existence of traditional arts, the regeneration process is essential by implanting the love for tradition to the children as the future generation.

For Javanese people, the notion of dance creation, including Warok dance, is heavily influenced by religious elements. Javanese people consider the religious aspects as traditional networking amidst social setting. They believe that the religious elements are impactful on their life as an individual or as a group. Concerning the concept of dance art as a cultural product, Koentjaraningrat [17] claims that "the eastern cultures prioritize spiritual, mystical, pre-logic, and hospitality values". Pamadhi [24] opines that such a view, including mystical and syncretic elements, as well as the idea of contributes to the aesthetical values of the art form. The view of the afterlife, therefore, is worth-investigating. In line with that, the Warok dance highly represents religious values. Some of the elements of spiritual in the dance that are maintained up to the present are the offerings and trance scene, where the dancers are possessed by spirits.

The offerings and trance scene are among the attractiveness of Warok dance performance. In addition to that, the dance's aesthetic elements are also attractive to the audience. The dance embeds aesthetic and educative values to the societal life, particularly in children. Despite this, the dance is currently drawing less and less attention from the community and the government. The supporting 
facilities and infrastructure to the performance of Warok dance are lacking. In the meantime, the scholarly discussion of Warok dance, particularly in its relation with children's aesthetical aspects, is yet to be explored. As a result, the existing literature that discusses the intertwinement of arts and children lacks variety, despite the fact that traditional dance and other performing arts are essential to imprint good values to the children. In line with that, Supanggah [30] argues that the values in traditional dance can strengthen the sense of brotherhood, togetherness, communal behavior, open-mindedness, tolerance, and peace.

As a social phenomenon, Warok dance represents the value of cooperation, togetherness, tolerance, sense of belonging, and harmony. Moreover, the dance is regarded as a personal medium for fulfillment of aesthetical needs. The present paper investigates the role of Warok dance as the medium of aesthetic needs for children. Warok dance is enjoyed by both adults and children alike. Therefore, the study specifically intends to elaborate the following: 1) the elements of Warok dance that function as the fulfillment and expression of children's aesthetic needs, and 2) the children's method of fulfillment of aesthetic needs.

\section{Discussion}

\subsection{Warok Dance}

As a performing art, Warok dance embeds aesthetical values that are attached to the form. The aspect of shape is integral to the presence of structures or components or other supporting materials. Jazuli [13] points out that body movements are closely related to dance movements. Dance movements refer to modified everyday movements (gerak wantah) or the stylization of everyday movements, which turns the moves to pure movements and gestures. The stylized everyday movements result in a visible artwork containing aesthetic values that people can enjoy. People's aesthetic values of art are developed as a medium of expression of the persons' viewpoint, aspirations, needs, and other ideas. The fulfillment of such values is defined by the cultural perspective; other cultures also play a main role in this process. Aesthetic values are of the significant aspects of people's beliefs. To this day, several art performances have been an integral part of various rituals. The notion echoes the result seen in Wuryaningrum [33] reporting that dance is among the art form functioning as a medium for specific rites.

Components shaping the aesthetic of Warok dance involve pure movements, gestures, and other supporting elements. For this reason, the aesthetic value of the dance is reflected in its shape and structure. Muklas [22] defines the term "structure" as a system in which it embeds the aspects intertwined, changed, and maintained with each other without depending on its core principle. Jazuli [10] regards structure as the existence of order, ignoring conflict and changes. Every structure in a social system is functional; it determines other structures within the system. The grounding of functional ideology lies in people: a social system containing several intertwined layers; each relies on others in harmony. The form and structure of a dance, according to Jazuli [12], can be seen from the whole dance performance with its supporting components, including accompanying music, theme, costume, makeup, setting, lighting, and sound system. All of these components generate a correlation in dance from several aspects, such as dynamics (speed, complexity, and power), dancers (number and sex of the dancers), visuals (setting and property), and setting (music, lighting, and sound system).

Aesthetic value is integral to a dance performance. Rohendi [25] asserts that art is an integrative element that incorporates different guidelines, combining these into a whole design accepted by many. Concerning this concept, the quality of the aesthetic values of Warok dance has been an interweaving entity that reflects a configuration of an art form. Consequently, children who learn this dance can appreciate and enjoy the aesthetic value of Warok.

Warok dance as an art mediates a communication process through its form and contents. The forms of Warok dance include movements, music, makeup, and costume. Therefore, the social function of this dance has something to do with the socio-cultural and religious activities of people. Human inevitably needs to sync with the surroundings or environment. Further, Koentjaraningrat [18] clarifies that art possesses a socio-cultural system taking form in a set of invaluable and impactful conceptions existed in the majority of people's mind. These conceptions are central to people's life. As a symbolic system interpreted through gestures (as its main medium), Warok dance contains its structures and meaning in a socio-cultural dimension. Kaplan [16] clarifies that a socio-cultural system, as an organism in which its components are interrelated, determines the maintenance of the stability of everything involved in the system. Simply put, the socio-cultural system owns its functional requirements, which are intended to enhance the existence of the system for surviving.

As Serbetar et al. [29] say that a positive and successful movement experience is critically important for every child's life, the involvement of children in Warok dance session is one of the preservation measures of the dance. As a result, up to this day, the dance's aesthetical values have ingrained to the people, either as individuals or as the whole community. Sarjiwo [28] states that the aesthetic value refers not only to the visual beauty of an object but also to something not visible to one's sight, which can only be perceived through one's consciousness and feeling. The notion provides an understanding that an individual, other than defining enjoyment objectively, 
finds pleasure in an art form through the messages implied from the art. Despite this, it is inevitable that an aesthetic art form encapsulates several aspects of wholeness, prominence, harmony, repetition and balance--all of which are perceivable through visual and auditory perception.

According to Susanto [31], the children's aesthetic experience is something perceived by human sense and it leads to the impression created by one's feelings. Junaedi [15] describes the term "aesthetic" as something possessing artistic values from the perspective of emotion or something concrete. Warok dance has the qualities of both the visual and auditory art form containing the aesthetic value. The visual aesthetic of the dance is visible from the expressive, dynamic, and attractive movements. Embedding rhythmical movements, the dance is accompanied by quick tempo music. The expressive component of the dance refers to movements delivered with appropriate expression to the theme of Warok dance, i.e., a depiction of a warrior reflecting his courage. Transitions in the dance are frequent that it illustrates the dynamics aspect. There are variations in the dance floor alignments, facing, and levels. High-level variation is represented by jumping moves, while the middle is seen in standing and squat position, and the low level is shown by its sliding movement all the way to lay down with a bit modification resulting in a similar handstand posture.

Muklas [22] asserts that the existence of moves, space, and time in a dance occur simultaneously along with the presence of the dancers on stages, resulting in the synchronous situation. Those three aspects are inseparable in a structural phenomenon of dances. In the qualities of a dance, the move-space-time correlation is also, by nature, correlative as the expression of an artist. For this reason, the structures of dance, such as the articulation, interweave with each other. The moves of Warok dance are performed lively with expression synced to the costume of the performers accompanied by fast tempo music and tintinnabulation sound from small bell-likes that the dancers wear in their costume. The energetic impression created from Warok dance incorporates spacious, bold, and powerful movements. Chanting of the dancers with the tintinnabulation produced from hundreds of klinthing (small bells) and upbeat music with quick tempo complement the impression of a brave warrior shown in colorful costume and the incorporation of blangkon (Javanese traditional cape), suitable to the dancers as a Warok (see Figure 2).

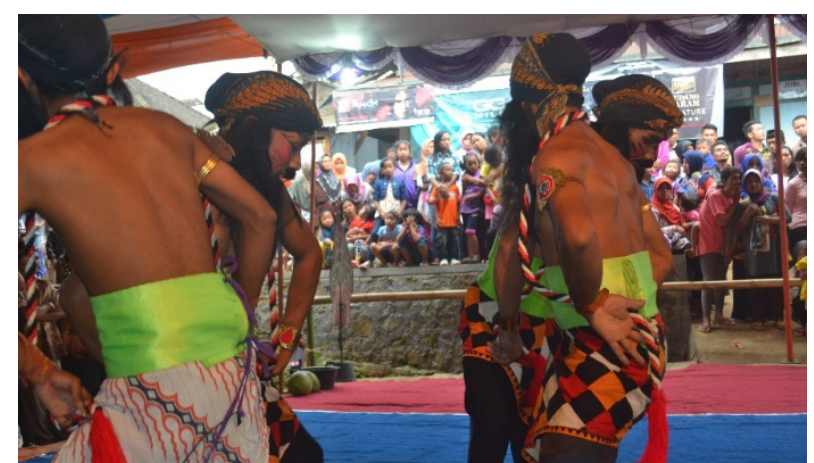

Figure 2. Warok dancers perform on stage in symmetrical formation

The aesthetic value of Warok dance lies in the harmony and balance attained from the impression of symmetrical and asymmetrical elements. The balance of the movements in Warok dance is made up from the impression of being equal in proportion, i.e., a pair of butterfly wings, or a fruit that is perfectly cut in half. The symmetrical movements represent the impression of tranquility and stability. In addition to that, the movements are represented by the combination of firm movements accompanied by upbeat music, slow movements accompanied by melancholic-theme music, slow tempo, and the emotional singing from the warang gono (male/female singers). The elements of symmetry are also displayed in the slow, swaying movements with accents of makeup and costume that enhance the impression of smoothness and finesse. As a whole process, the symmetrical form accentuates the notion of simplicity; it is reflected from the social reality of the community in which the Warok dance is practiced and preserved. The notion of simplicity is represented from the social life, in which there is no significant gap on social stratification.

The asymmetrical element of the dance results in a dynamic, fluctuating impression. Jazuli [10] regards is as a principle of aesthetic form created by contrasting, yet symbiosis elements that lead to an integral object. Asymmetry in the dance provides accentuates a dynamic and lively situation. The combination of firm movements and slow movements is viewed as the harmony in diversity. The same also applies in the combination of slow movements and loud music, and the combination of slow movements and "bold" makeup and costume. The facial expressions, spontaneous movements, and the incorporation of jokes/humor, accompanied with dynamic and rhythmic music, creates an impressive art show. Therefore, the harmonization in the dance performance functions to create the element of attractiveness, as well as enjoyable and satisfying experience to the audience. 
For children, the aesthetic elements in the Warok dance accompaniment music are an unforgettable experience. The dance and its accompaniment music is an inseparable unity. The loud and expressive music stimulate the dancers to be more expressive, arousing, energetic, dynamic, and attractive; such expressions will spark joy to the dancers and the audience alike. In addition to that, the instruments of jidor (drum-sounds produced by membrane-covered musical instruments), kendang (drum-sounds produced by membrane-covered musical instruments), and saron (musical instrument of Indonesia that has seven bronze bars placed on top of a resonating frame and is played on the floor by a seated performer). The performance also accompanied with the dancers' shouts, create a lively performance.

The accompaniment of musical instruments with varying tempo from the upbeat to slow indicates the dynamic condition of the community. It expresses the value of courage, responsibility, persistence, and discipline. The situation during the dance show seems to boost the motivation of the audience to work hard. It illustrates a simple lifestyle and, at the same time, the tenacity, courage, steadfast of the people in living their life, aiming for a better future.

The harmonious atmosphere between the dance and the symbols or values that the community adheres to indicates the aesthetic value of Warok dance that is shaped by various choreographic elements of dance. Choreographic elements refer to aspects that originated from the surroundings that are used to satisfy the entertainment, social, and religious needs of people.

In addition to create a lively atmosphere, the musical instruments also function to emphasize the dancers' expressions. Individually, the unique expressions are apparent on each dancer's facial gesture, while as a unity, the unique expressions are represented in the floor pattern formation (see Figure 3). The most dominant patterns involve a straight line and only a few that incorporate a circle shape. A straight line represents the characteristic of firmness and seriousness. Variations of facing direction and level further add the lively situation during the dance show. This situation demands every dancer to be disciplined, brave, and responsible in the performance, including the collaboration among the dancers in the group. The prominent impression of Warok dance is the combination of strong, bold, and soft moves, producing a firm and humane image. Such a combination also presents an art form with an emphasis on audience enjoyment, as well as the delivery of values the dance embeds in the form of a performance.

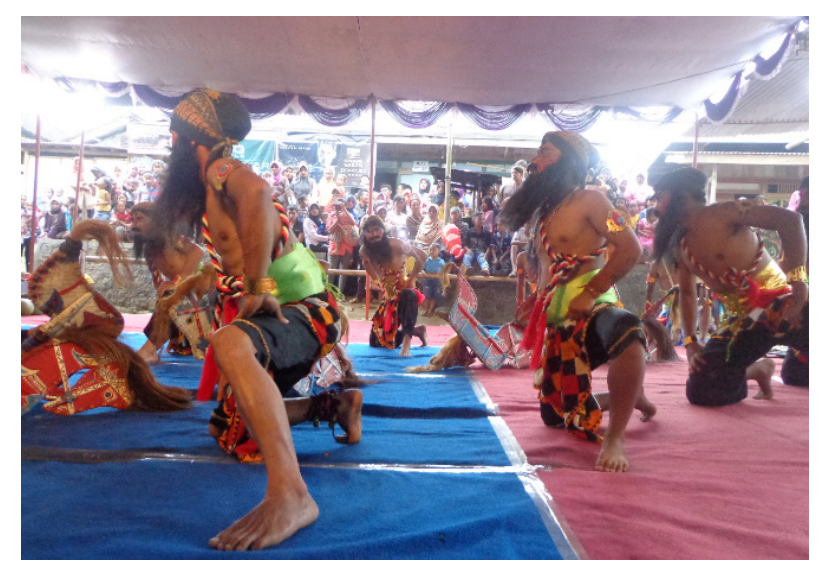

Figure 3. Expressive moves of Warok dancers

The elements of makeup and costume are also important in the whole context of Warok dance performance. The incorporation of makeup and costume enhances the children's pride and confidence when performing the dance in front of the audience (see Figure 4). Besides, the additions of such elements help creat an enjoyable performance. It is worth noting, however, that not all traditional dances in Java take serious concern on the makeup and costume due to the financial limitation. With such limitation, the art performers and the audience are still entertained if the show still goes on.

Essentially, all human beings, including children, require expressing their need for aesthetics to feel joyful and satisfied. Such feelings are not only gained when the children performed, but also in the pre-show preparations.

The aesthetic values of Warok dance are beneficial for children as the medium of fulfillment of the children's aesthetic needs. In addition to that, the Warok dance is also regarded as the manifestation of a human expression that contains knowledge, experiences, ideas, and values that are represented artistically in the form of symbols. Koentjaraningrat [18] argues that cultural value is essential and valuable to the life of an individual as guidance for one regarding the appropriate orientation in societal life.

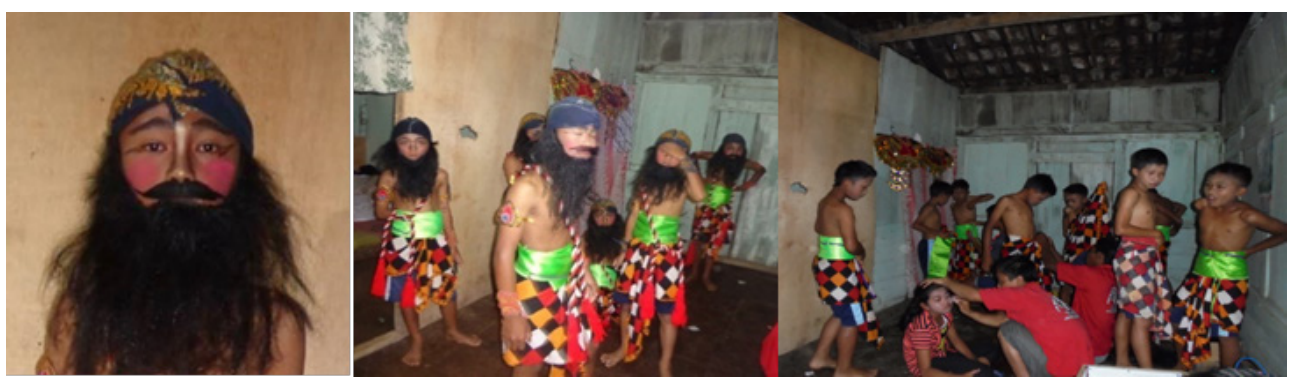

Figure 4. The children's aesthetic experience during the makeup and dressing session 


\subsection{Appreciation}

According to Verbeek [32], appreciation is defined as the awareness to evaluate an artwork by involving all the feeling, experiences, desire, and assumption. In addition to that, appreciation functions as the medium to increase one's affection and care towards others. Further, appreciation also acts as the means of evaluation, entertainment, emphatic expression, education, and capacity development. Aesthetically, it is seen as the evaluation of a beauty. In arts field, appreciation is emphasized on the aspect of observation towards an artwork.

The artwork appreciation expressed by the children is also seen as the effort to preserve the Warok dance. The dance has its elements that shape this dance as an art form. Those elements, according to Jazuli [14], must meet the principle of unity, harmony, balance, rhythm, proportion, and emphasis. Up to this day, the dance is still present and enjoyed by the community. In regard to this, Rohidi [26] mentions some characteristics of group arts. First, the group arts are a product of shared ideas; this type of art embeds and reflects the view of a particular group. Second, the group arts are the pride of a community. Third, the group arts emerge due to the recognition of other groups of people during the interaction in a social setting.

In addition to that, the Warok dance is traditional performing arts that involve the collective elements. Regarding this, the dance is designed to be performed in public so that the audience too can experience the aesthetic elements of the dance. Moreover, as a traditional form of art, the dance is passed down from generations. Jazuli [11] regards that a traditional object is highly related to the events in the pastimes; therefore, the object accentuates symbols, myths, values, ideas, habits, beliefs, norms, and traditions.

As a traditional, folk performing art with educative values, the incorporation of Warok dance in children education is therefore deemed as a paramount significance. A study by Hartono \& Sari [6] has shown that learning traditional dances allows children to shape their attitudes and behaviors, given the positive values and norms incorporated in a dance. These values stimulate children's rational, systematic, and critical thinking. Over and above that, the children also learn how to be disciplined. Hartono [4] further asserts that every child has his or her multiple intelligences, and learning dances are central to the development of this aspect.

Children aesthetic experience occurs since the pre-performance stage, i.e., the rehearsal, makeup and dressing session, and during the performance. The appreciation of aesthetic, harmonious, energetic, and attractive movements is accompanied by the music from the traditional instruments, e.g., saron (musical instrument of Indonesia that has seven bronze bars placed on top of a resonating frame and is played on the floor by a seated performer), kendang (drum-sounds produced by membrane-covered musical instruments), and bende (a traditional musical instrument whose body shape is like a small form of gongs during the Montholan stage. During the process, the children experience an aesthetic process that a performing art is to be enjoyed and appreciated. Therefore, the dynamics of performing arts calls for serious concerns in terms of the design, so that all participants involved can express their need for self-indulgence.

The balance in a Warok dance performance is seen from the start. During the start of show, the tempo of the musical instruments is upbeat and loud; the tempo then goes slow, reducing the tension of the audience and the performers (see Figure 5). The dynamics of upbeat-low tempo is capable of drawing the attention of people nearby to watch and enjoy the dance. The expressive makeup, the costume (such as kuluk or head accessory), the trouser, and pant of the dancers contributes to their agility and speed in the performance, depicting the image of a brave, persistent warrior in facing every challenge. Such elements add up to the lively atmosphere of the show.

As an art form, Warok dance possesses a unique, absolute value functioned as a medium for people to express the ideas, knowledge, and aesthetic feeling. Hartono et al. [7] claim that such feeling needs to be stimulated since young ages to ensure the effectiveness of this process. Art activities serve as the medium to instill aesthetic values intentionally and unintentionally. For example, a study by Kusumatuti and Hartono [19] clarifies the benefit of teaching Kuda Debog dance to instill aesthetic values and to develop the maturity of children in social activities. It is expected that the dance learning shapes the students' character better. This notion is in line with the result seen in Ichtiara [9] and Giranti [3] that art learning is effective for character building due to the instilment of aesthetic value. The above discussion also emphasizes that arts are a medium of expression other than its function for entertainment. In a positive direction, children involved in dance learning can develop their aesthetic values and, at the same time, social skills. Learning dance is not only about learning the moves of the dance. This activity enables one to learn the principles of life. 


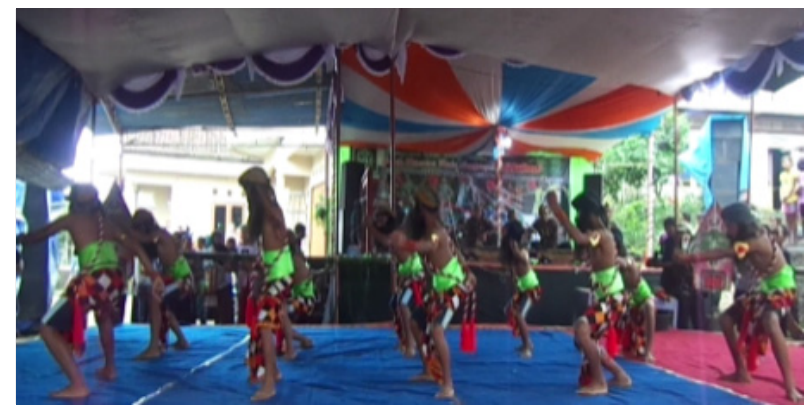

Figure 5. The warok dancers show expressive, dynamic, and attractive movements

Warok dance has a communication function, given its function as a medium of expression of a person and a social group (see Figure 6). According to Rohkyatmo [27], dance is a series of rhythmical, beautiful moves that express human feelings. Another study from Enoch [2] reveals that dance is a medium to inform a certain event through body expressions and gestures. These two notions imply that dance is an expression of aesthetic value for the artists and audiences. Hartono \& Lanjari [5] report the potential of teaching Kuda Lumping dance (through its moves and accompanying music) as a medium of children's aesthetic development.

Dewar [1] reports that dance has its communicative and social functions. The social function of a dance correlates with creating artistic images. Some consider that this is a crucial concept, which is actualized in a social setting.

For some people, those with higher social statuses often hold an art performance, inviting others to watch and enjoy the show. People with higher social statuses consider this as a means to get their satisfaction. Their satisfaction comes from the feeling of happiness as those of the upper class can provide an enjoyable art performance to the community. This notion indicates the existence of an art form as an integral part of human existence through its function as a means of achieving life satisfaction. Dance is not only about something concrete but also something abstract associated with the inner side of human, e.g., feeling. Mind satisfaction can be expressed through symbols, and these symbols are interpreted in dance moves, in a dimension of time and space. Mukhlas [22] argues that the existence of dance is integral to human. In this context, it is worth-noting that the main purpose of dancing is to express oneself, to achieve personal satisfaction represented in symbols. The symbols reflected in dance moves signify that human is capable of capturing concrete, whole objects.

According to Langer [20], symbols embed the principle of communication. Humphrey [8] adds that symbols transform human experiences and reality into dance. Dance as a whole art performance is inseparable from the interpretation of reality. The reality or phenomenon is perceived and transformed cognitively into a symbol. Consequently, the creation of a symbol occurs whenever the subject meets the real situation, resulting in a symbolic transformation accumulated in experiences. There are direct (primary) and indirect (secondary) literal symbols in Warok dance.

Warok dance possesses a literal symbol of the embodiment of the people to express their existence in cultural activities through art performances. Warok dance, from the indirect or secondary perspective, is an entertainment for people and those who involved directly in the dance. On top of that, the dance is a means to express and channel the creativity of art enthusiasts through dancing, playing a musical instrument, reciting the poem accompanying the dance; these require skills and expertise. Although some dancers may be amateurs, the opportunity to practice the dance and deliver their best in a show is effective in cultivating aesthetic values. Human aesthetic needs are, by nature, something universal. Rohidi [26] mentions that people, in addition to their primary needs, seek the opportunity to satisfy their aesthetic needs. They need a medium to express their sense of beauty. The most common example to achieve this is through the arts.

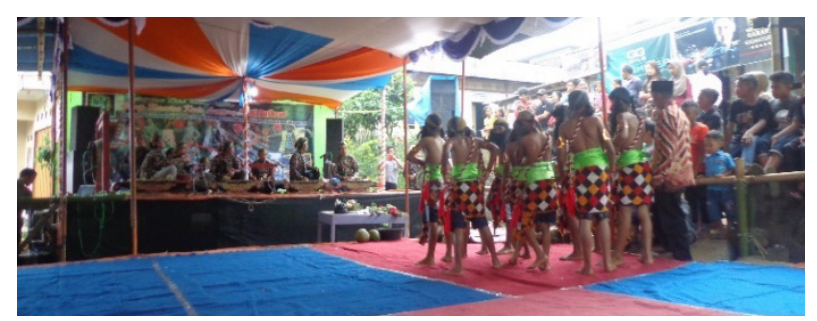

Figure 6. Communication between dancers, instructor, and musician before the dance performance

Attempts to fulfill the aesthetic needs of people through Warok dance are shown by their willingness to allocate budget (i.e., buying costly costumes or costumes) to deliver an impressive art performance. They are also willing to spend their time on the dance show. Although they may not receive any profits and get tired (since the whole performance can take from noon to night), they get their satisfaction as the recognition of their hard work. Some Warok dancers have other activities after the performance. They are eager to participate in the dance show for satisfying their aesthetic needs and channel their creativity.

\section{Conclusions}

The aesthetic elements in Warok dance comprise movements, music, makeup, and costume. These elements serve as the medium to fulfil the children's aesthetic needs. The aesthetic values of the movements are apparent in the dynamic, expressive, energetic, and attractive dance movements. In addition to those elements, the adaptation to the floor pattern formation in dancing also sparks their satisfaction. The aesthetic experience is also represented from the auditory and visual senses of the musical 
instruments. This process occurs when the children listen to the musical accompaniment that takes the form of song, melody, rhythm, and tempo; the children also experience the aesthetics of the visual appearance of the musical instruments, the ornaments, and the decorations. Children's fulfilment of aesthetics needs is also expressed through the components of the dancers' costume of the dancers, i.e., the model of the costume, color selection, and combination of colors.

By participating in the whole performance sequence, the children fulfil their aesthetic needs unintentionally, both as active and passive appreciators of the dance. The appreciation of the dance is not only seen as the medium to express and channel the children's hobbies, but also as the support system of the preservation of Warok dance.

\section{REFERENCES}

[1] Dewar P, "Adopting a Performance Model From Ethnomusicology: The Task and Tools Outlined In a Study Of Inuit Drum Dance," Journal of Dance Ethnology, vol 15, pp. 16, 1991 .

[2] Enoch A, "Drama Tari sebagai Suatu Bentuk Karya Seni" in Pengetahuan Elemen Tari dan Beberapa Masalah Tari," Direktorat Kesenian, 1986, pp. 186.

[3] Giranti, Haq A, Hartono, Lestari W, "Character Education Values in Retno Tanjung Dance Performance As An Identity Dance of The City of Tegal," Journal of Arts Education, vol 8, no 3, pp. 313-320, 2019.

[4] Hartono, "Pengembangan Kecerdasan Jamak Dalam Kegiatan Pembelajaran Tari Gajah Melin di TK Negeri Pembina Kabupaten Kendal," MUDRA Journal of Cultural Arts, vol. 27, no. 2, pp.214-223, 2012.

[5] Hartono, Lanjari R, "Kuda Lumping Dance as Learning Media to Fulfill Aesthetical and Expression Development of Children," Arts and Design Studies, vol 68, pp.55-65, 2018.

[6] Hartono, Sari Y, "Character Building for Early Childhood: A Case Study of the Teaching of Performing and Fine Arts," Proceedings of the $5^{\text {th }}$ International Conference on Science, Education, and Technology, June, 2019. http://dx.doi.org/10.4108/eai.29-6-2019.2290454

[7] Hartono, Susetyo B, Fitriani, "Tarek Pukat Dance Learning to Improve Learning Activities of Early Childhood," 2nd International Conference on Arts and Culture, Oct, 2019, pp.134-137.

[8] Humphrey D, "(The Art of Making Dance)," in Seni Menata Tari,” Dewan Kesenian Jakarta, 1983, pp. 78.

[9] Ichtiara, Wijaya D, Hartono, Triyanto, "The Art of Dabus Indragiri in Rantau Mapesai as a Medium to Build Character," Catharsis Journal, vol 7, no 1, pp. 69-76, 2018.

[10] Jazuli M., "Aesthetic of Dance Research Model: A Case Study on Keprajuritan Dance in Semarang Regency," HARMONIA: Journal of Arts and Education, vol.15, no. 1, pp. 16-24, 2012.
[11] Jazuli M, "Optimalisasi Seni Pertunjukan Tradisional dalam Jagad Pendidikan Seni," Seminar Nasional Seni Pertunjukan dan Pendidikan Seni, Semarang, Indonesia, Oct, 2016, pp. $32-43$.

[12] Jazuli M, "Paradigma Kontekstual Pendidikan Seni," Unesa University Press Surabaya, 2008, pp. 13.

[13] Jazuli M., "Pendidikan Seni Budaya," Semarang: UNNES Press, 2008, pp. 13 (b)

[14] Jazuli M, "Sosiologi Seni: Pengantar dan Model Studi Seni", Graha Ilmu , 2011, pp. 27.

[15] Junaedi D, "Estetika Jalinan Subjek, Objek, dan Nilai," ArtCiv, 2016, pp. 18.

[16] Kaplan D, Manner AR, "Culture Theory,” Waveland Press, 1989.

[17] Koentjaraningrat, "Kebudayaan Mentalitas dan Pembangunan," Gramedia, 1982.

[18] Koentjaraningrat, "Pengantar Ilmu Antropologi,” PT Rineka Cipta, 2009, pp. 153.

[19] Kusumastuti E, Hartono, “Kuda Debog Dance for Children's Social Development," International Journal of Sciences and Research, vol. 73, no. 6, pp. 355-371, 2017. http://dx.doi.org/10.21506/j.ponte.2017.6.30.

[20] Langer SK, "Philosophy in a New Key," Harvard University Press, 1957.

[21] Miles BM, Huberman A. M., "Qualitative Data Analysis," $2^{\text {nd }}$ ed, Sage Pub, 1994.

[22] Mukhlas A, "Tari Sebagai Gejala Kebudayaan :Studi Tentang Eksistensi Tari," KOMUNITAS International Journal of Indonesian Society and Culture, vol. 4, no. 2, pp. $129-132,2012$.

[23] Murgiyanto S, "Tradisi dan Perubahan: Tidak ada Jalan Pintas untuk Hasil Berkualitas: Menyimak Tari Tradisi di Indonesia," Seminar Nasional Seni Pertunjukan dan Pendidikan Seni, Semarang, Indonesia, Oct, 2016, pp. 15-31.

[24] Pamadhi H, “Tinjauan Sosiologis Landasan Idil Seni Rupa Klasik Menurut Konsepsi Jawa,” FBP IKIP Yogyakarta, 1985.

[25] Rohendi TR, "Ekspresi Seni Orang Miskin," Penerbit Nuansa, 2011

[26] Rohidi RT, "Kesenian dalam Pendekatan Kebudayaan," STSI Press, 2000.

[27] Rohkyatmo A, "Pengetahuan Tari Sebagai Sebuah Pengantar," Direktorat Kesenian, 1986, pp. 74.

[28] Sarjiwo, "Olah Tubuh dalam Perkspektif Pembelajaran Wirasa Tari,” Jurnal Ilmiah Seni \& Budaya Panggung, vol 18, no. 2, pp.147-159, 2008.

[29] Serbetar I, Loftesnes JM, Prprovic I, "Disparities in Motor Competence between Roma and Non-Roma Children in Croatia and Relations of Motor Competence, School Success and Social Economic Status," International Journal of Human Movement and Sports Sciences, vol 7, no. 2, pp. 19-24. https://doi.org/10.13189/saj.2019.070201 
[30] Supanggah R., "Kesenian Tradisional, (Kebudayaan Nasional, Peranan dan Sumbangannya dalam Membentuk Karakter Bangsa," Seminar Nasional Seni Pertunjukan dan Pendidikan Seni, Semarang, Indonesia, Oct, 2016, pp. 6-14.

[31] Susanto M., "Diksi Rupa Kumpulan Istilah dan Gerakan Seni Rupa," Dikti Art Lab, 2011, pp. 124.
[32] Verbeek P. P. C. C., "Morality in Design: Design Ethics and the Morality of Technological Artifacts," in Philosophy and Design: from Engineering to Architecture, Springer, 2008, pp. 91-103. https://doi.org/10.1007/978-1-4020-6591-0_7

[33] Wuryaningrum A, Sumaryono T, Hartono, "Ritual Interaction in the Soneyan Mask Puppet," The Journal of Educational Development, vol 5, no. 2, pp. 252-262, 2017. 